\title{
Türkiye'de Bilirkişilik Kanunu Açısından Adli Muhasebe İhtiyacına Yönelik Bir Değerlendirme
}

\author{
Harun ÖĞÜNÇ ${ }^{1 *}$ \\ ${ }^{1}$ Asst. Prof. Dr, Burdur Mehmet Akif Ersoy University, Bucak Zeliha Tolunay School of Applied Technology \\ and Management, Department of Accounting and Financial Management, Burdur, Turkey
}

Geliș Tarihi/Received: 23.03.2020

Kabul Tarihi/Accepted: 09.05.2020

Derleme Makalesi/Review Article

\section{ÖZET}

Mahkemeye intikal eden veya etme aşamasında olan parasal konuların araştırılması için bazı ülkelerde adli muhasebecilerden faydalanılmaktadır. Türkiye'de ise bilirkişilik faaliyetine ait kanun bulunmasına rağmen henüz adli muhasebe ile ilgili yasal bir düzenleme mevcut değildir. Bu çalışmada Türkiye'deki bilirkişilik faaliyeti ile adli muhasebecilik karşılaştırılmış ve bilirkişilik yasasının adli muhasebecilik açısından eksik yönleri ortaya koyulmuştur. Buna ek olarak, adli muhasebe kapsamında olası anlaşmazlık durumlarına ilişkin örneklere yer verilmiştir. Bu kapsamda adli muhasebecinin araştırma yaparken hangi araçlardan yararlanması gerektiği üzerinde durulmuştur.

Anahtar kelimeler: Adli Muhasabe, Bilirkişilik Kanunu.

\section{An Assessment of the Need for Forensic Accounting in Terms of Expertise Law in Turkey}

\begin{abstract}
Forensic accountants are used in some countries to investigate monetary issues that have been brought to court or have not yet been filed. In Turkey, there are laws related expertise; however, there isn't legal regulation on forensic accounting yet. In this study, the expertise activity is compared with forensic accountancy and the shortcomings of the expertise law in terms of forensic accountancy have been revealed. In addition, examples of possible dispute situations are given within the scope of forensic accounting. In this context, it has been focused on which tools the forensic accountant should use while conducting research.
\end{abstract}

Keywords: Forensic Accounting, Expertise Law.

* Sorumlu yazar/Corresponding author

E-mail/e-ileti: ogunc@mehmetakif.edu.tr 


\section{Öğ̈̈̈nç, $H$.}

\section{GíRíş}

Bireylerin veya işletmelerin hukuktan ayrı bir yaşam sürmeleri düşünülemez. Çünkü herhangi bir işlemi gerçekleştiren birey veya işletmenin, ortaya çıkaracak sonuçlardan sorumlu tutulacağının bilincinde olması gerekmektedir. Dolayısıyla özellikle parasal işlemler sonucunda meydana gelen çıkar çatışmaları gibi nedenlerle hak kaybı yaşadığını iddia eden taraf, adli merciler aracılığıyla hakkını aramaktadır. Bu noktada, hukuk sistemi içerisinde bulunanların mali konularda yeterli bilgi ve tecrübeye sahip olmaması nedeniyle muhasebe mesleğini icra edenlerden faydalanmaları kaçınılmazdır. Dolayısıyla adalet sisteminin unsurları olan hâkim, savcı ve avukat ile davacı ve davalı tarafından muhasebe mesleğini ilgilendiren hususlarda bilgisine başvurulan bu kişiler, adli muhasebe kapsamına giren konuların aydınlatılmasında önemli bir rol oynamaktadır.

İşletmelerde gerçekleşen usulsüzlükler şüphesiz ki sadece günümüzün konusu değildir; ancak günümüzde yolsuzlukların bu ölçüde fazla ortaya çıkartılmasının temel nedeni, denetim sistemlerinin gelişmiş olması, bilgilerin bilgisayar ortamında sürekli olarak kontrol edilebiliyor olması ve dolayısıyla birçok usulsüz olayın hızı bir şekilde ortaya koyulabilmesidir. Ancak aynı imkanlar, suç işlemeyi kolaylaştıran bir araç veya işlenen suçun gizlenmesi için bir perde görevi de görebilmektedir. $\mathrm{Bu}$ nedenle kayıtlarda, belgelerde veya finansal tablolarda sunulanlarla yetinilmeyip detaylı bir araştırma yapılması ve görünenin arkasında başka gizlerin de bulunabileceğinin bilincinde olunması gerekmektedir. Söz konusu inceleme işlemleri denetim faaliyetinin ötesine geçen daha detaylı bir süreci gerektirmekte olup adli muhasebe ve adli muhasebecilik kapsamında değerlendirilmektedir.

Bu çalışmada mevcut yasal düzenlemeler dikkate alınarak adli muhasebecilik mesleği ile bilirkişilik faaliyeti karşılaştırılmış ve adli muhasebe konularının aydınlatılmasında Bilirkişilik Kanunu'nun ne düzeyde kullanılabileceği ortaya koyulmuştur. Ayrıca adli muhasebecinin karşılaşabileceği dava konuları ve araştırma yaparken hangi araçlardan faydalanabileceği, örnekler üzerinden incelenmiştir.

\section{ADLİ MUHASEBE}

Adli muhasebe (forensicaccounting) terimini ilk olarak 1946 y1lında, New York'ta bir muhasebecilik şirketinin ortağı olan Maurice Peloubet, "Forensic Accounting: Its Place in Today’s Economy” isimli çalışmasında kullanmıştır (Açık, 2016: 1074). 1980’li yıllardan itibaren batı ülkelerinde gelişmeye başlayan adli muhasebecilik mesleği (Pazarçeviren, 2005: 
2); muhasebe, denetim ve inceleme (soruşturma) becerilerine ihtiyaç duyulması durumunda hukuki süreçte rol oynamaktadır. Dolayısıyla bu faaliyetin icra edilmesi, muhasebecilik mesleğinin ötesine geçmeyi, çok daha detaylı bir araştırma sürecini koordine etmeyi ve hatta “altıncı hissini” kullanabilme özelliğine sahip olmayı gerektirmektedir (forensicaccounting.com).

Henüz Türkiye'de yasal bir zemine oturmamış olan adli muhasebe, mahkemeye intikal etmiş olsun veya olmasın, hukuki bir anlaşmazlığın esaslı bir boyutunu muhasebeyi ilgilendiren ihtilafların oluşturması halinde psikoloji, suç bilimi vb. alanlardan da yararlanan, kendine özgü analiz, araştırma ve sorgulama teknikleri kullanarak gerçeği arayan bir bilim dalıdır (Gülten, 2010: 312).

Adli muhasebe faaliyetini icra edenler için kullanılan adli muhasebecilik mesleği, mafya lideri Al Capone'un mahkemesi sürecinde ün kazanmıştır. Bu davada Al Capone'un yakalanmasından sorumlu takım içerisinde yer alan bir muhasebeci, vergi kaçıran $\mathrm{Al}$ Capone'un takibinde önemli bir rol oynamış ve ilk yüksek profile sahip adli muhasebeci olarak anılmıştır. Söz konusu takımın avantajı, olağanüstü düzeyde soruşturma ve parçaları bir araya getirme yeteneklerine sahip üyelerden oluşmasıydı. Buradan hareketle adli muhasebecinin aşağıda sıralanan özelliklere sahip olması gerektiği söylenebilir (Aktaş ve Kuloğlu, 2008: 108113):

- Temel eğitim düzeyine sahip olmalı ve ilgili alanda devamlı olarak ileri düzeyde eğitim almalidir.

- Kamu ve özel sektörü kapsayacak şekilde geniş bir muhasebe ve denetim tecrübesine sahip olmalıdır.

- Sözel ve yazılı iletişim becerisine sahip olmalıdır.

- Pratik işletme tecrübesine ve çeşitli konularda adli denetleme tecrübesine sahip olmalidir.

- Takım içerisinde çalışma yeteneğine sahip olmalıdır.

- Sosyal becerisi ve esneklik düzeyi yüksek olmalıdır.

Bilgisi ve kullandığı teknikler açısından oldukça önemli bir role sahip olan adli muhasebeciye avukatlar, güvenlik güçleri, bankalar ve sigorta şirketleri, mahkemeler, 


\section{Ö̆̆̈̈̈ç, $\boldsymbol{H}$.}

işletmeler, hükümet temsilcileri ve hükümete bağlı tüzel kişiler ihtiyaç duyabilmektedir (Pazarçeviren, 2005: 4). Adli muhasebecilerin fayda sağladığı konular ise aşağıdaki gibi siralanabilir (forensicaccounting.com/four.htm):

a) Cezai Soruşturmalar: Genellikle polis kuvvetleri tarafindan yapılan soruşturmalarda polis güçleri veya barolar tarafından adli muhasebeciler tutulabilmektedir.

b) Hissedar Anlaşmazlıkları: Hissedarlar arasındaki anlaşmazlıkların aydınlatılması için muhasebe kayıtlarının adli muhasebeciler tarafından detaylı incelenmesi gerekebilmektedir.

c) Kişisel Yaralanma ve Motorlu Taşıt Kazaları: Bir motorlu taşıt kazasından kaynaklanan ekonomik kayıpların belirlenmesi ve tıbbi uygulama hataları gibi konularda yardım talep edilmektedir.

d) İşin Kesintiye Uğraması ve Sigorta Alacakları: Sigortalı ve sigortacının anlaşmazlığı durumunda tazminat tutarının ve diğer kayıpların tespiti için ve çalışan sahtekârlığından kaynaklanan kayıpların da belirlenmesi için yardım talep edilmektedir.

e) İşletme veya Çalışanlarla İlgili Dolandırıcılık Araştırmaları: Fonların takibi, varlıkların belirlenmesi ve kurtarılması, çalışanların dolandırıcılık faaliyetini gerçekleştirdiğinin belirlenmesi ile bu faaliyetin kapsamının ortaya koyulması gibi konularda yardım talep edilmektedir.

f) Evlilik Anlaşmazlıkları: İşletme varlıkları ve gayrimenkuller gibi unsurların evlilik uyuşmazlıklarında izlenmesi için yardım talep edilmektedir.

g) İşletmenin Ekonomik Kayıpları: Sözleşme ihtilafları, kamulaştırmalar, mamul yükümlülügünün yerine getirilmemesi, ticari marka ve patent ihlalleri gibi nedenlerle ortaya çıkan zararın tespiti için yardım talep edilmektedir.

h) Mesleki İhlaller: Genel kabul görmüş muhasebe ilkeleri ile denetim standartları gibi standartların ihlal edilmesi durumunda oluşan kayıpların tespiti için yardım talep edilebilmektedir.

1) Arabuluculuk ve Tahkim: Yasal konular ve süreçlere aşina olmaları nedeniyle adli muhasebecilerden arabuluculuk gibi konularda hakemlik yapmaları için de yardım alınabilmektedir. 


\subsection{Adli Muhasebenin Temel Faaliyetleri}

Adli muhasebe çok çeşitli konularda anlaşmazlıkların çözümü ve hak kaybının önlenmesini sağlamakta olup bu faaliyetleri dava desteği, bilirkişi tanıklı̆̆ ile hile ve suistimal ile yolsuzluk araştırmacılığı olmak üzere üç temel üzerine oturtmak mümkündür. Bunlardan dava desteği, dava konusu olayda mağdur konumunda bulunan tarafa, avukata ve mahkemeye bilgi sağlamayı kapsamaktayken; bilirkişi tanıklığı, mahkemede sadece sözlü olarak görüş bildirmek olarak ifade edilebilir. Hile araştırmacılığı ise denetim faaliyetinin adli muhasebeye özgü tekniklerle yerine getirilmesidir (Gülten, 2010: 313). Sözü edilen bu faaliyetler aşağıda açıklanmıştır.

\subsection{Dava Desteği}

Dava desteği, ekonomik zararın ölçülmesi başta olmak üzere muhasebe alanına giren konularda destek olmayı ifade etmekte olup (forensicaccounting.com) dava desteği sağlayan adli muhasebeci aşağıdaki konularda ilgili taraflara bilgi sağlamaktadır (Gülten, 2010: 316):

- Boşanmalarda tarafların mal paylaşımı sürecinde mal kaçırma faaliyetinin gerçekleşmesinin açıklığa kavuşturulmasında,

- İşletmenin mali kaybının ortaya çıkması için zararın tespiti işleminde,

- Belge, çek, senet ve kredi kartı dolandırıcılıklarında,

- Hileli iflas uygulamalarında borçlunun mal kaçırmak için muvazaalı işlemlerinin aydinlatılmasinda,

- İşçi tazminatları ve iş hukukunda ortaya çıkan usulsüzlüklerin ortaya çıkartılmasında,

- Vergi hileleri ve yolsuzluklarının ortaya çıkartılması ile mali tablolarda veya defterlerdeki hesap oyunlarının tespit edilmesinde,

- Ortaklara kâr dağıtımı, tasfiye ve birleşme gibi ticaret hukukunu ilgilendiren birçok olayda,

- Kara paranın aklanması durumunun ortaya çıkartılmasında. 


\section{Öğ̈̈̈nç, $H$.}

\subsection{Uzman Tanıklık (Bilirkişi Tanıklığı)}

Türkiye'de, alanında uzman kişilerin mahkemeye yazılı bir raporla bilgi vermesi şeklinde gerçekleştirilen bilirkişilik faaliyetinin doğrudan sözlü olarak icra edilmesi, uzman tanıklık olarak adli muhasebede yer bulmaktadır. Dolayısıyla, raporda net olarak anlaşılmayan açıklamalar nedeniyle sürecin uzaması veya yanlış anlamalar sonucunda adaletin sağlanamaması durumunun önüne geçilmekte ve mahkemede doğrudan soru-cevap şeklinde uzman kişinin bilgisine başvurulmakta; hâkim, savcı ve avukatın aydınlatılması sağlanmaktadır (Gülten, 2010: 317). Bu kapsamda adli muhasebecinin uzman tanıklık faaliyetindeki görevleri: gerekli araştırmayı yaparak verileri toplamak, bu verileri analiz edip bir görüşe sahip olmak ve bu görüşü mahkemede ayrıntılı ve açık bir şekilde sunmaktır (Aksu vd., 2008: 64). Dolayısıyla uzman tanıklık görevinin yerine getirilebilmesi için aşağıdaki mesleki niteliklere sahip olunmas1 gerekmektedir (Reinstein ve Lander, 2004: 52):

- Teknik Yeterlilik: İş alanında danışmanlık tecrübesi, istatistik, şimdiki değer hesaplama, ekonomi ve enflasyon muhasebesi, finansal analiz ve maliyet uzmanlığı, şirketlerde birleşme ve devralma, uzun dönem bütçeleme, tahmin, simülasyon ve finansal model geliştirme gibi bazı alanlarda eğitimli olma, teknik yeterliliğin göstergeleri olarak sayılabilmektedir.

- Bağımsızlık: Bilirkişilerin davalı veya davacıya yönelik önyargı taşımamaları gerekmektedir ve bu kapsamda bilirkişinin bağımsızlığının tespit edilmesi için gerekli araştırma ve çapraz sorgulamalar yapılmaktadır.

- Öngörü: Bilirkişi, dava konusu olayla ilgili gerekli çalışmaları yapmak ve hazırlanmak için yeterli zamanı belirleyebilmelidir.

- Açıklık: Bilirkişi, karmaşık ve anlaşılmaz herhangi bir nokta kalmaması için konuyu gerekli ölçüde açık bir şekilde sunabilmelidir.

\subsection{Hile, Suistimal ve Yolsuzluk Araştırmacılığı}

Türk Dil Kurumu sözlüğüne göre hile: "birini aldatmak, yanıltmak için yapılan düzen, dolap, oyun, ayak oyunu, alavere dalavere, desise, entrika" olarak ifade edilirken suistimal ve yolsuzluk ise "görev, yetki vb.ni kötüye kullanma" olarak tanımlanmaktadır ve bu kapsamda gerçekleştirilen araştırmalarda genellikle işgören hırsızlığı, gayrimenkul veya sigorta dolandırıcılığı, rüşvet gibi cezai konular incelenmekte olup söz konusu olay gerçekleşmeden veya gerçekleştikten sonra adli muhasebeciden yardım talep edilmektedir (Aksu vd., 2008: 64). 
Adli muhasebecinin; hile, suistimal ve yolsuzluk araştırması yaparken aşağıdaki hususlara dikkat etmesi gerekmektedir (Gülten, 2010: 319):

- Adli muhasebeci, çalışmasında uygulayacağı metodu kendisi belirlemelidir.

- İşletme yönetiminin ve işletme ortaklarının niyet ve beklentilerini tespit etmeye çalışmalı ve çalışanların uymak zorunda olduğu işletme kurallarını incelemelidir.

- İşletme dışındaki alıcı ve satıcı gibi unsurlara ait araştırmalar yapmalıdır.

- İşletmede hangi noktalarda hile yapılabileceğini tahmin edip iç kontrol sisteminin zayıf olduğu alanları tespit edebilmelidir.

- Elinde kesin kanıt bulunmadan kimseyi doğrudan suçlamamalıdır.

- Suç işlediğini düşündüğü kişinin psikolojik yapısını dikkate alarak itiraf etmesini veya açık vermesini sağlamaya çalışmalıdır.

- Gerektiğinde kendisi de bir uzmandan (bilgisayar yazılımcısı gibi) destek almalıdır.

- Hile, suistimal ve yolsuzluk sonucunda uğradığı kaybın tespit edilmesi ve yeniden benzer olaylarla karşılaşmaması için işletmenin bilgilendirilmesi gerekir.

\section{LITERATÜR}

Literatür incelendiğinde adli muhasebe konusunda çok sayıda çalışmanın yapıldı̆̆ı görülmektedir ve bunlardan bazıları aşağıda sunulmuştur.

Pazarçeviren (2005), adli muhasebecilik mesleğini ele aldığı çalışmada bu mesleğin kapsamını, örnek olaylardan da faydalanarak adli muhasebe sürecini, adli muhasebecinin sahip olması gereken özellikleri ve aldığı eğitimleri açıklamıştır.

Aktaş ve Kuloğlu (2008), adli muhasebecilik kavramı ve adli muhasebenin tarihçesinden söz ettiği çalışmada mesleğini icra edecek kişilerde bulunması gereken özellikleri ve adli muhasebeciliğin temel ilkelerini açıklamıştır.

Aksu vd. (2008), adli muhasebecilik ve bunun bir kolu olarak bilirkiş̧iliği ele aldığ çalışmada bilirkişinin taşıması gereken özellikler, bilirkişilerin görev ve sorumlulukları ile bilirkişi hataları gibi konularda detaylı bilgilendirmede bulunmuştur. 


\section{Öğ̈̈̈ç, $H$.}

Kurt ve Uçma (2009), adli muhasebeci olabilmek için gerekli olan koşulları ABD'deki yasal düzenlemeler açısından ele almış ve Türkiye' deki mevcut durumla karşılaştırmıştır.

Gülten (2010) gerçekleştirdiği çalışmada adli muhasebe kavramını ve adli muhasebecilik mesleğinin kapsamına giren dava desteği, uzman tanıklık ve suistimal, hile ve yolsuzluk araştırmacılığı hakkında açıklamalarda bulunmuştur.

Kasap (2013), aklama suçu kapsamında adli muhasebeyi ele aldığı çalışmada adli muhasebenin bağımsız denetimle ilişkisi ve aklama suçunun ortaya çıkarılmasında adli muhasebenin oynadığı rol üzerinde durmuştur.

Al (2014), adli muhasebenin kurumsal, stratejik, operasyonel ve yönetsel kararlar yanında yatırım, finansman ve kâr payı dağıtımı kararları üzerindeki etkilerini detaylı şekilde incelemiştir.

Ciğer ve Topsakal (2015) tarafından yapılan çalışmada Antalya ilindeki serbest muhasebeci mali müşavirler ile avukatların dâhil edildiği anket çalışmasıyla adli muhasebecilerde bulunması gereken özellikler ortaya koyulmaya çalışılmıştır. Ayrıca üniversitelerde lisans eğitiminde adli muhasebeyle ilgili derslerin verilmesi gerektiği üzerinde durulmuştur.

Açık (2016), adli muhasebecilik mesleğine ilişkin detaylı açıklamalar verdiği çalışmada bu meslekte faaliyet gösterecek olanların almaları gereken eğitimler ve Türkiye'de henüz bir meslek olarak yer bulmayan adli muhasebeciliğin yasal bir zemine oturtulması için yapılması gerekenler üzerinde durmuştur.

Akyel (2016), adli muhasebe eğitiminin Türkiye'de sınırlı seviyede verildiği ve hukuk eğitiminde de muhasebeye yeterince yer verilmemesi nedeniyle karar alıcıların mali konularda bilirkişilere sürekli olarak başvurmak zorunda kaldığı üzerinde durmuştur.

Pamukçu (2017), adli muhasebe ile bağımsız denetim faaliyetini karşılaştırdığı çalışmada bu ikisi arasındaki benzer ve farklı yönleri geniş ölçüde açıklamıştır.

Çayır ve Akın (2018), adli muhasebe kapsamında yönetim hilelerini inceledikleri çalışmada Burdur ve Isparta illerindeki adli vakaları analiz etmiş ve yorumlamıştır. 
Kısacık (2018), adli muhasebe ile 6754 sayılı bilirkişilik kanunu kapsamında bilirkişiliği incelediği çalışmada, söz konusu kanundaki ilgili maddeleri ve muhasebe bilirkişilerinin uzmanlık alanına giren konuları sıralamıştır.

Çeliker ve Aygün (2018), Van ilindeki muhasebe meslek mensupları ve avukatlarının adli muhasebe konusundaki farkındalık düzeylerini ölçmeye yönelik bir çalışma gerçekleştirmiştir.

Öztürk vd. (2019), TRA 2 bölgesindeki devlet üniversitelerinde muhasebe ve finansman alanındaki akademisyenlerin adli muhasebe konusundaki farkındalıkları, adli muhasebe eğitiminin yeterliliği ve bu konuda ihtiyaç duyulan derslerin belirlenmesi üzerine çalışma yapmışlardır. Bu çalışmada adli muhasebe eğitimine yönelik yeterli düzeyde ders verilmediği, ayrıca müfredata bu konuda ders eklenmesiyle ilgili planlarının da olmadığı sonucuna ulaşılmıştır.

Kızıl vd. (2019), adli muhasebenin hangi alanlarda kullanılabileceği ve adli muhasebecilerin faaliyetlerinde hangi araçlardan faydalanabilecekleri üzerine bir çalışma yapmışlardır.

Özdemir (2019), konkordato projesi çalışmalarının hem hukuki hem de mali bir niteliğe sahip olması ve bu projenin reddedilmesinin, telafisi imkânsız sonuçlara yol açabilmesi nedeniyle konkordato öncesinde ve başvuru sürecinde detaylı inceleme, araştırma ve değerlendirmeye yönelik olarak adli muhasebecilerden faydalanılmasının gerekliliği üzerine bir çalışma ortaya koymuştur.

Karslığlu ve Karavardar (2019), Trabzon ilinde faaliyet gösteren muhasebe meslek mensuplarının adli muhasebe farkındalıklarını araştırdıkları çalışmada adli muhasebe konusunda çok az bilgiye sahip oldukları ve genel olarak bilirkişilik faaliyetinin adli muhasebecilik olarak bilindiği ortaya koyulmuştur. Ayrıca adli muhasebeye ilişkin eğitim verilmesi durumunda bunun stajla desteklenmesi gerektiği düşünülmektedir.

\section{ADLİ MUHASEBECILIIK MESLEĞí ILLE BİLİRKIŞiLİIK FAALIYYETININ KARŞILAŞTIRILMASI}

30143 sayılı Resmi Gazete'de yayımlanan Bilirkişilik Yönetmeliği md. 4'e göre bilirkişi, “çözümü uzmanlığı, özel veya teknik bilgiyi gerektiren hâllerde oy ve görüşünü sözlü veya yazılı olarak vermesi için başvurulan gerçek veya özel hukuk tüzel kişisini” ifade 


\section{Öğ̈̈̈nç, $H$.}

etmektedir. Aynı yönetmelikte yer alan md. 5 ise bilirkişinin dikkat edeceği temel ilkeleri aşağıdaki şekilde belirtmektedir:

Tablo 1. Bilirkişinin dikkat edeceği temel ilkeler

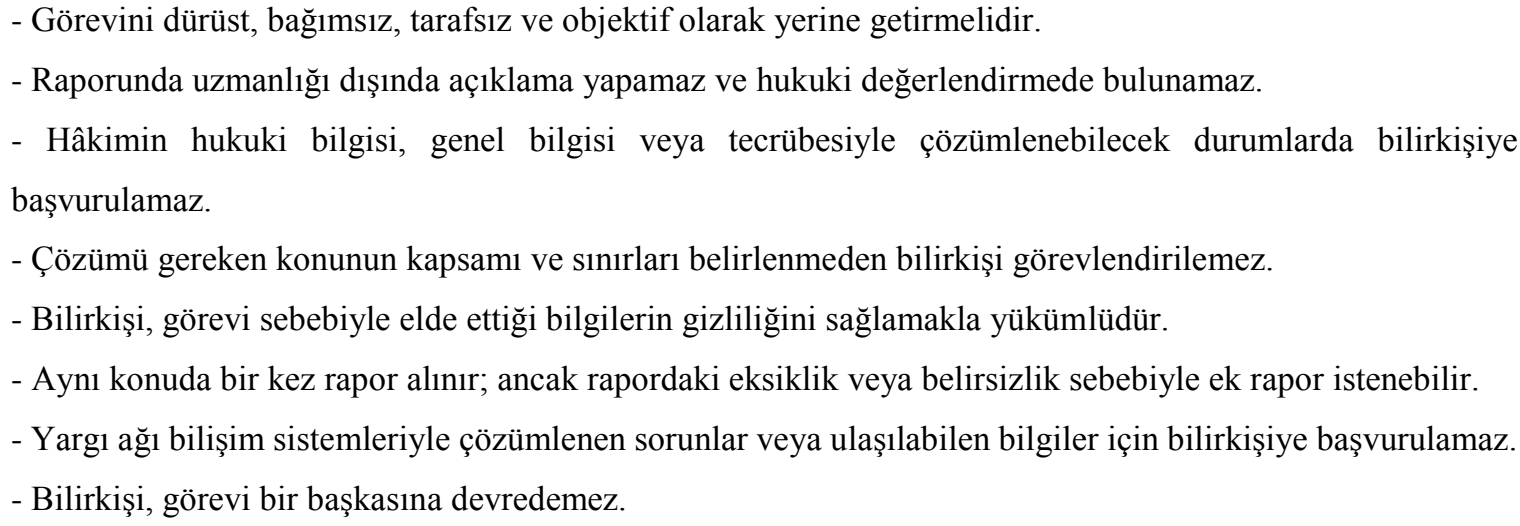

Kaynak: https://bilirkisilik.adalet.gov.tr/dokumanlar/2017/agustos/Bilirki\%C5\%9Filik\%20Y\%C3\%B6netmeli \%C4\%9Fi.pdf, Erişim tarihi: 13.01.2019

Görevin dürüst, bağımsız, tarafsız ve objektif bir şekilde yerine getirilmesi ve sadece alanıyla ilgili olarak bilgi sunması açısından bilirkişi ile adli muhasebeci aynı yönde özellikler taşımaktadır. Buna karşılık bilirkişi rapor halinde görüş bildirmesine rağmen adli muhasebeci duruşmada sözlü olarak, taraflardan gelecek sorulara açık bir şekilde aynı görevi icra etmektedir. Bilirkişilik Yönetmeliği md. 56'ya göre bilirkişiye görev veren merci, rapordaki eksikliği veya anlaşılmazlığg gidermesi için yeni sorular yönelterek bilirkişiden ek rapor talep edebilmektedir. İhtiyaç duyulması halinde bilirkişinin görüşü sözlü olarak da alınabilmektedir. Hukuk Muhakemeleri Kanunu md. 293'e göre ise taraflar dava konusu olayla ilgili olarak uzman görüşüne başvurabilmektedir; ancak ayrıca süre talebinde bulunulamamaktadır. Hâkim, kendisinden rapor alınan uzman kişinin duruşmada dinlenmesine karar verebilmektedir. $\mathrm{Bu}$ durumda hâkim ve taraflar, uzmana gerekli soruları sorabilmektedir. Dolayısıyla bilirkişi duruşmada sözlü olarak görüş bildirmeyip sadece hâkim ve savcıya sözlü olarak bilgi aktarabilirken uzman olarak bilgisine başvurulan kişi ise duruşmada sözlü olarak tüm taraflara görüş bildirebilmektedir.

Adalet Bakanlığı Hukuk İşleri Genel Müdürlüğü bünyesinde kurulan Bilirkişilik Daire Başkanlığı tarafından izin verilmesi koşuluyla bilirkişilik temel eğitimi, aşağıda sıralananlar tarafından verilebilmektedir (Bilirkişilik Yönetmeliği, md. 33): 
Tablo 2. Bilirkişilik temel eğitimi verebilecek olanlar

\begin{tabular}{|l|l|}
\hline - Üniversiteler & - Türkiye Serbest Muhasebeci Mali Müşavirler ve Yeminli Mali \\
- Türkiye Adalet Akademisi & Müşavirler Odaları Birliği (TÜRMOB) ve bağlı odalar \\
- Adli Tıp Kurumu & - Türkiye Esnaf ve Sanatkârları Konfederasyonu ve esnaf ve \\
- Türkiye Barolar Birliği ve barolar & sanatkârlar odaları \\
- Türk Tabipleri Birliği ve bağlı odalar & - Türk Mühendis ve Mimar Odaları Birliği ve bağlı odalar \\
- Türkiye Odalar ve Borsalar Birliği & \\
\hline
\end{tabular}

Kaynak: https://bilirkisilik.adalet.gov.tr/dokumanlar/2017/agustos/Bilirki\%C5\%9Filik\%20Y\%C3\%B6netmeli \%C4\%9Fi.pdf, Erişim tarihi: 13.01.201

Bilirkişilik faaliyetini icra edecek olanlara, Tablo 2'de yer alan kurum, oda ve birliklerden ilgili olanlar tarafından eğitim verilebileceği belirtilmiştir. Ancak adli muhasebe açısından bunları ele aldığımızda Tablo 3 'te sunulduğu gibi birincisi muhasebe, ikincisi ise hukuk olmak üzere iki aşamalı olarak eğitim verilmesi, adli muhasebecilik mesleğinin daha etkin bir şekilde icra edilmesini sağlayacaktır.

Tablo 3. Adli muhasebe eğitimi

\begin{tabular}{|l|l|}
\hline \multicolumn{1}{|c|}{$\begin{array}{c}\text { Muhasebe Açısından Teorik ve } \\
\text { Uygulamalı Eğitim }\end{array}$} & \multicolumn{1}{c|}{$\begin{array}{c}\text { Hukuk Açısından } \\
\text { Teorik ve Uygulamalı Eğitim }\end{array}$} \\
\hline - Üniversiteler & - Türkiye Adalet Akademisi \\
- TÜRMOB ve Bağlı Odalar & - Türkiye Barolar Birliği ve Barolar \\
\hline
\end{tabular}

Bilirkişilik temel eğitiminin alınabilmesi için gerekli koşullar ise Bilirkişilik Yönetmeliği md. 30'da aşağıdaki şekilde belirtilmiştir:

Tablo 4. Bilirkişilik temel eğitiminin alınabilmesi için gerekli koşullar

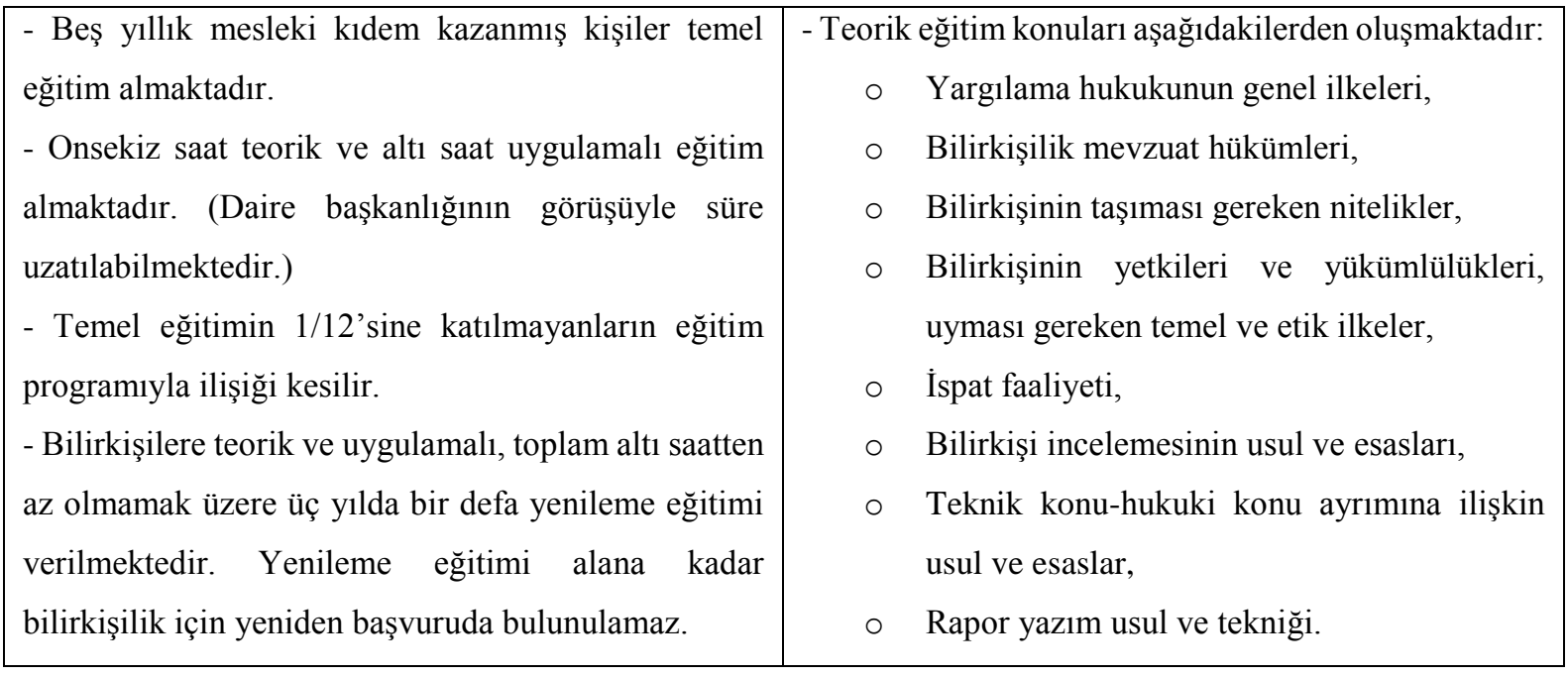

Kaynak:https://bilirkisilik.adalet.gov.tr/dokumanlar/2017/agustos/Bilirki\%C5\%9Filik\%20Y\%C3\%B6netmeli\% 
Bilirkişilik temel eğitimine katılmanın ilk koşulu olarak beş yıl mesleki deneyim şartının bulunması, bu faaliyeti icra edecek kişinin mesleki birçok konuya hâkim olması anlamına gelmektedir. Dolayısıyla adli muhasebe eğitiminin daha çok hukuk üzerine olması gerekecektir. Ancak her ne kadar mesleki tecrübeye sahip olsa da adli sürece dâhil olmuş mali konular hakkında eğitim alması, adli muhasebecinin karşılaşabileceği konulara daha şüpheci yaklaşmasını sağlayacaktır.

Adli muhasebe faaliyetini icra edecek kişilerin alması gereken belli başlı eğitimler ve bu eğitimler sonucunda elde etmeleri beklenen bazı yeterlilikler ise Tablo 5'te sıralanmıştır (Açık, 2016: 1084):

Tablo 5. Adli muhasebeciler için gerekli eğitimler ve yeterlilikler

\begin{tabular}{|l|l|l|}
\hline \multicolumn{2}{|c|}{ Gerekli Eğitimler } & \multicolumn{1}{c|}{ Gerekli Yeterlilikler } \\
\hline - Yönetim Bilimi & - İletişim Sistemleri & - Araştırma ve Detaylı İnceleme \\
- İşletme Bilimi & - Hile Denetimi & - Analitik Düşünebilme \\
- Muhasebe Teorisi & - İstatistik & - Doğru Yorumlayabilme \\
- Denetim & - Psikoloji & \\
- İç Kontrol Sistemi & - Sosyoloji & \\
- Bilgi Teknolojileri & - Kriminoloji & \\
- Halkla İlişkiler & & \\
\hline
\end{tabular}

Kaynak: Açık, S. (2016). Adli muhasebecilik mesleğinin faaliyet alanları ve eğitim boyutu açısından incelenmesi. Atatürk Üniversitesi Sosyal Bilimler Enstitüsü Dergisi, 20(3), 1084.

Yukarıda sıralanan "gerekli eğitimler"in bazıları lisans öğrenimi sürecinde alınmaktadır. Ancak özellikle iletişim sistemleri, hile denetimi, istatistik, psikoloji, sosyoloji ve kriminoloji eğitiminin uygulamalı olarak ve örnek olaylar üzerinden adli muhasebeci adaylarına verilmesi gerekmektedir.

\section{ADLİ MUHASEBE KAPSAMINDA DEĞERLENDİRİLEBİLECEK ÖRNEKLER}

Araştırılması ve aydınlığa kavuşturulması gereken birçok konuda muhasebe işlemlerinin tarafı konumundaki işletmelerin, bireylerin veya devlet organlarının adli muhasebecilerden faydalanması gerekebilmektedir. Bu çerçevede ele alındığı zaman adli muhasebeye konu olabilecek durumlara ilişkin örnekler aşağıda verilmiştir. 
Tablo 6. Adli muhasebe kapsamındaki örnekler ve yapılacak araştırmalar

\begin{tabular}{|c|c|c|}
\hline $\begin{array}{l}\text { Adli } \\
\text { Muhasebeciye } \\
\text { İhtiyaç Duyan } \\
\text { Taraf }\end{array}$ & Adli Muhasebe Kapsamındaki Konu & $\begin{array}{l}\text { Adli Muhasebecinin Yapması } \\
\text { Gereken Araştırmalar }\end{array}$ \\
\hline Şirket & $\begin{array}{l}\text { Şirket aracımızın karıştığı kazada karşı taraf } \\
\text { alkollü olmasına rağmen alkol ölçümü } \\
\text { yapılmamıştır ve bunun sonucunda şirket } \\
\text { aracımız trafik sigortasından daha az oranda } \\
\text { faydalandırılmıştır. }\end{array}$ & $\begin{array}{l}\text { - Sürücünün alkol aldığına ilişkin bir } \\
\text { veri var mı? Varsa ne kadar alkol aldığı } \\
\text { bilgisi elde edilebiliyor mu? } \\
\text { - Alkol ölçümü yapılmamasının nedeni } \\
\text { araştırılacak. “İlgili sürücü nüfuzunu mu } \\
\text { kullandı?” sorusunun cevabı aranacak. }\end{array}$ \\
\hline Şirket & $\begin{array}{l}\text { Şirket aracının karıştığı kazada yaralananların } \\
\text { tedavileri özel bir hastanede yapılırken gereksiz } \\
\text { tahlil ve görüntüleme işlemleri nedeniyle yüksek } \\
\text { tutarda fatura şirketimize gönderilmiştir. }\end{array}$ & $\begin{array}{l}\text { - Benzer bir olayda hangi tahlil ve } \\
\text { görüntüleme işlemlerinin yapılması } \\
\text { gerektiği araştırılacak. } \\
\text { - } \mathrm{Bu} \text { işlemlere ait yansıtılan tutarın } \\
\text { normal aralığı belirlenecek. }\end{array}$ \\
\hline Şirket & $\begin{array}{l}\text { Şirketimiz tarafından } \text { gerekli iş sağlığ ve } \\
\text { güvenliği önlemleri alınmasına rağmen } \\
\text { personelimiz kendi kusuru sonucunda } \\
\text { yaralanmış; buna rağmen tazminat talebinde } \\
\text { bulunmuştur. }\end{array}$ & $\begin{array}{l}\text { - Gerekli güvenlik önlemlerinin olaydan } \\
\text { önce alınıp alınmadığı tespit edilecek. } \\
\text { - Personelin kusuru araştırılacak. }\end{array}$ \\
\hline Şirket & $\begin{array}{l}\text { Personelimiz şirkete ait olmayan araç için aldığı } \\
\text { yakıt bedellerini şirkete ödetmiştir. }\end{array}$ & $\begin{array}{l}\text { - Faturadaki tarih ve saatte şirket } \\
\text { aracının konumu belirlenecek. } \\
\text { - Faturayı düzenleyen işletmenin } \\
\text { belirtilen gün ve saatte kamera kayıtları } \\
\text { incelenecek. }\end{array}$ \\
\hline
\end{tabular}


Tablo 7. Adli muhasebe kapsamında örnekler ve yapılacak araştırmalar (tablo 6 devam)

\begin{tabular}{|c|c|c|}
\hline $\begin{array}{c}\text { Adli } \\
\text { Muhasebeciye } \\
\text { İhtiyaç Duyan } \\
\text { Taraf }\end{array}$ & Adli Muhasebe Kapsamındaki Konu & $\begin{array}{l}\text { Adli Muhasebecinin Yapması } \\
\text { Gereken Araştırmalar }\end{array}$ \\
\hline Şirket & $\begin{array}{l}\text { Şirket araçlarının yenilenmesinden sorumlu } \\
\text { personel, anlaştığı kişilere piyasa değerinden } \\
\text { daha düşük fiyatla araç satış yaparak aradaki } \\
\text { fiyat farkını kendi lehine kullanmıştır. }\end{array}$ & $\begin{array}{l}\text { - Aynı özelliklere sahip başka araçların } \\
\text { ilgili tarihteki ortalama satış fiyatı tespit } \\
\text { edilecek. } \\
\text { - Satış yapılan kişilerle satışı yapan } \\
\text { personel arasındaki bağ araştırılacak. }\end{array}$ \\
\hline Şirket & $\begin{array}{l}\text { Patenti şirketimize ait olan bir ürünü bir başka } \\
\text { işletme taklit ederek üretmiş ve satmaktadır. }\end{array}$ & $\begin{array}{l}\text { - Patent tescil süresinin geçerliliği } \\
\text { kontrol edilecek. } \\
\text { - Eğer süre sona ermişse bunun tarihi } \\
\text { belirlenecek. }\end{array}$ \\
\hline Şirket & $\begin{array}{l}\text { Tedarikçi işletmeyle yapılan anlaşmaya göre } \\
\text { verilen malzeme siparişi } 24 \text { saat içerisinde } \\
\text { işletmemize ulaştırılmak zorundadır; ancak bu } \\
\text { sürede teslimat gerçekleşmemiştir. }\end{array}$ & $\begin{array}{l}\text { - Tedarikçinin malzemeyi işletmeye } \\
\text { ulaştırma saati ile talebin gönderildiği } \\
\text { saat karşılaştırılacak. } \\
\text { - Saat bilgilerine ilişkin kayıt (kamera, } \\
\text { e-mail vb.) incelenecek. }\end{array}$ \\
\hline Şirket & $\begin{array}{l}\text { Ürün, müşteri tarafından zamanında teslim } \\
\text { alınmadığı için tazeliğini kaybetmiş ve müşteri, } \\
\text { kendisi kusurlu olmasına rağmen bu ürünlere ait } \\
\text { ödemeyi yapmıyor. }\end{array}$ & $\begin{array}{l}\text { - Müşterinin ürünü teslim alması için } \\
\text { yeterli süre verildi mi? } \\
\text { - Bilgilendirme ve teslimatla ilgili saat } \\
\text { bilgilerine ilişkin kayıt (kamera, e-mail, } \\
\text { telefon vb.) mevcut mu? }\end{array}$ \\
\hline Şirket & $\begin{array}{l}\text { Alacaklı olduğumuz işletme iflas etmiş ve } \\
\text { işletmenin varlıkları işletme sahipleri tarafından } \\
\text { kaçırılmıştır. }\end{array}$ & $\begin{array}{l}\text { - İşletme varlıklarının kaçırıldığına } \\
\text { ilişkin belge, bilgi, kayıt vb. } \\
\text { incelenecek. } \\
\text { - Kaçırma eylemi öncesi ve sonrasına } \\
\text { ilişkin varlık bilgileri incelenecek. }\end{array}$ \\
\hline Şirket & $\begin{array}{l}\text { Yangın nedeniyle stoklar değersiz duruma } \\
\text { gelmiştir; ancak bilirkişi tarafından yapılan } \\
\text { değer tespitinde stokların sadece } \% 30 \text { değer } \\
\text { kaybına uğradığı belirlenmiştir. }\end{array}$ & $\begin{array}{l}\text { - Yangın raporu incelenecek. } \\
\text { - Stokların son durumuna ilişkin } \\
\text { görüntüler incelenecek. }\end{array}$ \\
\hline Şirket Ortağ & $\begin{array}{l}\text { Diğer ortaklar, şirket kasasındaki nakdi, kişisel } \\
\text { ihtiyaçları için kullanıyor; ancak bununla ilgili } \\
\text { olarak şirkete faiz ödemesi yapmıyorlar. }\end{array}$ & $\begin{array}{l}\text { - Nakit hareketleri incelenerek fatura ve } \\
\text { irsaliyelerle karşılaştırılacak. } \\
\text { - İrsaliye tarihindeki stok hareketlerine } \\
\text { ait görüntüler incelenecek. } \\
\text { - Ödeme işlemini ne şekilde yaptığına } \\
\text { ilişkin bilgi alıcılardan elde edilecek. }\end{array}$ \\
\hline
\end{tabular}


Tablo 8. Adli muhasebe kapsamında örnekler ve yapılacak araştırmalar (tablo 7 devam)

\begin{tabular}{|c|c|c|}
\hline $\begin{array}{l}\text { Adli } \\
\text { Muhasebeciye } \\
\text { İhtiyaç Duyan } \\
\text { Taraf }\end{array}$ & Adli Muhasebe Kapsamındaki Konu & $\begin{array}{l}\text { Adli Muhasebecinin Yapması } \\
\text { Gereken Araştırmalar }\end{array}$ \\
\hline Ahmet C. & $\begin{array}{l}\text { Boşanma aşamasındaki Dilek } \mathrm{C}, \text { evlilik } \\
\text { sonrasında edinilen varlıkların } \\
\text { kapsamış̧ısımı } \\
\text { devretmiştir. }\end{array}$ & $\begin{array}{l}\text { - Varlıkların dava öncesi ve } \\
\text { sonrasındaki miktarları karşılaştırılacak. } \\
\text { - Varlıkların kime aktarıldığı } \\
\text { incelenecek. }\end{array}$ \\
\hline İşçi & İşçilere fazla mesai ücreti verilmemektedir. & $\begin{array}{l}\text { - İlgili tarihte ve saatte faaliyetin devam } \\
\text { ettiğine ilişkin belge ve kayıtlar } \\
\text { incelenecek. } \\
\text { - Fazla çalışma ücreti verilmeyen işçinin } \\
\text { ilgili tarihte ve saatte çalıştığına ilişkin } \\
\text { kayıtlar incelenecek. } \\
\text { - Diğer çalışanlardan konuyla ilgili bilgi } \\
\text { alınacak. } \\
\text { - Servis aracının fabrikaya giriş ve } \\
\text { çıkışlarına ait bilgiler elde edilecek. }\end{array}$ \\
\hline
\end{tabular}

Yukarıda adli muhasebe kapsamında ortaya çıkabilecek bazı örnekler verilmiş olup adli muhasebeci detaylı inceleme faaliyetlerinde bulunarak bu sorunların çözümüne yönelik girişimlerin sonuçlanmasına yardımcı olacaktır.

\section{SONUÇ}

Adli muhasebecilik, konusu para olan neredeyse tüm adli konularda kişilerin, işletmelerin veya hâkim, savcı ve avukatların faydalanabileceği bir meslek olarak karşımıza çıkmaktadır. Yabancı hukuk sistemlerindeki örnekler ele alındığında oldukça etkin bir şekilde faaliyet gösteren bu meslek, Türk hukuk sistemi içerisinde yasal bir zemine oturmamış olsa da bilirkişilik faaliyeti, adli muhasebeciliğin eksikliğini gidermeye çalışmaktadır. Bilirkişilik kanunu kapsamında uygulanan bilirkişilik faaliyeti, muhasebe açısından yeterli bir çerçeve sunmakla birlikte teorik ve uygulamalı hukuk konularında yetersiz bir görünüm ortaya koymaktadır. Ayrıca bilirkişiler duruşmada sözlü olarak sunum yapamazken uzman olarak duruşmaya katılanların sözlü sunum yapması mümkün olmaktadır. Dolayısıyla adli muhasebeci, bilirkişinin ve uzmanın birleşimi gibi görünmekle birlikte yine de bunlar tam olarak adli muhasebeci kavramını karşılayamamaktadır; çünkü adli muhasebeci diğer 


\section{Öğ̈̈̈nç, $H$.}

muhasebeciler tarafindan da görülebileni duruşmada anlatan kişi değil, görünmeyeni ortaya koymak için araştıran, sezgi sahibi, şüpheci özelliğe sahip kişidir.

Sadece çalışma hayatında değil; kişilerin kişilerle, işletmelerle veya devletle olan tüm ilişkilerinde (genellikle parasal konularda) ortaya çıkabilecek anlaşmazlık durumlarında adli muhasebecilerden yararlanılabilmektedir. Varlıklara ilişkin sigorta tazminatları ve varlık değerinin tespiti, işletme personeli ile anlaşmazlık durumları ve personelin zimmetine para geçirmesi, iş kazaları, tedarikçiler ve alıcılarla anlaşmazlık durumları başta olmak üzere araştırılması ve detaylı bir şekilde incelenmesi gereken birçok konunun çözüme kavuşturulması gerekebilmektedir. Ancak sözü edilen konulara ilişkin detaylı araştırma yapılabilmesi için yasal bir dayanak gerekmektedir ve mevcut yasal düzenlemeler buna imkân vermemektedir. $\mathrm{Bu}$ nedenle TÜRMOB çatısı altında; Ticaret Hukuku ile Muhasebe ve Finansman biliminde eğitim faaliyetlerinde bulunan akademisyenler ve adli muhasebeciliği uygulayan uzmanlar bir araya gelerek çalıştaylar düzenlenmesi ve bu çalıştaylardan ortaya çıkan sonuçlara istinaden gerekli yasal zeminin oluşturulması ve sağlıklı bir biçimde hayata geçirilmesi önerilmektedir.

\section{REFERENCES / KAYNAKLAR}

Açık, S. (2016). Adli muhasebecilik mesleğinin faaliyet alanları ve eğitim boyutu açısından incelenmesi. Atatürk Üniversitesi Sosyal Bilimler Enstitüsü Dergisi, 20(3), 1071-1090.

Aksu, İ., Uğur, A. \& Çukacı, Y. C. (2008). Adli muhasebe ve adli muhasebecilik mesleğinin bir kolu olarak bilirkişilik. Yönetim ve Ekonomi Araştırmaları Dergisi, 9, 63-71.

Aktaş, H. \& Kuloğlu, G. (2008). Adli muhasebe ve adli muhasebecilik mesleği. Muhasebe ve Denetime Bakış, Mayıs, 8(25), 101-120.

Akyel, N. (2016). Adli muhasebe çerçevesinde hukuk eğitiminde muhasebe derslerinin önemi. 3. Uluslararası Muhasebe ve Finans Araştırmaları Kongresi (ICAFR 16) Özel Sayısı, 95-108.

Al, A. (2014). Adli muhasebe ve karar alma arasındaki ilişkilerin finansal kararlar açısından değerlendirilmesi. Mali Çözüm Dergisi, 125, 95-124.

Bilirkişilik Yönetmeliği. $\quad$ (2017). $\quad$ Erişim $\quad$ tarihi: $\quad 13.01 .2019$, http://bilirkisilik.adalet.gov.tr/dokumanlar/2017/agustos/Bilirki\%C5\%9Filik\%20Y\%C3\%B6netmeli\%C4\%9Fi.p df.

Ciğer, A. \& Topsakal, Y. (2015). Adli muhasebecilik mesleğine genel bakış: Adli muhasebe eğitiminin faydaları ve engelleyicileri. Akdeniz I.I.'B.F. Dergisi, (31), 70-88.

Çayır, E. \& Akın, O. (2018). Adli muhasebe kapsamında yönetim hileleri, Burdur ve Isparta illeri adli vaka analizleri. Bucak Işsletme Fakültesi Dergisi, 1(1), 71-89.

Çeliker, F. \&Aygün, M. (2018). Adli muhasebe ve ilgili tarafların algı düzeyleri: Van örneği. Van YYÜ İ̈BF Dergisi, 3(6), 151-166. 
Forensic Accounting Demystified. Erişim tarihi: 01.02.2019, https://forensicaccounting.com/

Gülten, S. (2010). Adli muhasebe kavramı ve adli müşavirlik mesleği. Ankara Barosu Dergisi, 68(3), 311-320.

Hukuk Muhakemeleri Kanunu. (2011). $\quad$ Erişim $\quad$ tarihi: 14.01 .2019 , http://www.mevzuat.gov.tr/MevzuatMetin/1.5.6100.pdf.

Karslığlu, İ. \& Karavardar, A. (2019). Adli muhasebe mesleğinin muhasebe meslek mensupları arasında farkındalığı: Trabzon SMMMO üyelerine yönelik bir araştırma. Muhasebe ve Denetime Bakış, (56), 141-164.

Kasap, M. (2013). Adli muhasebecilik mesleği ve aklama suçuyla mücadele. Çankırı Karatekin Üniversitesi İktisadi ve İdari Bilimler Fakültesi Dergisi, 3(1), 121-132.

Kısacık, H. (2018). Adli muhasebe ve 6754 sayılı bilirkişilik kanunu kapsamında muhasebe bilirkişiliği. International Congress on Social Sciences II (INCSOS 2018 Quds), (13/15), 291-303.

Kızıl, C., Akman, V. \& Yılmaz, B. (2019). Adli muhasebe ve adli muhasebecilik mesleğine genel bir bakış. Beykent Üniversitesi Sosyal Bilimler Dergisi, 12(1), 58-73.

Kurt, G. \& Uçma, T. (2009). Adli muhasebecilik mesleği ve adli muhasebeci olabilme sürecinin Türkiye'deki ve Amerika'daki yasal düzenlemeler açısından karşılaştırılması. Ticaret ve Turizm Eğitim Fakültesi Dergisi, (2), 160178.

Özdemir, M. (2019). Konkordato talebinde adli muhasebe desteği. Balkan ve Yakın Doğu Sosyal Bilimler Dergisi, 5(2), 16-22.

Öztürk, S., Topal, A. \& Kaya, Y. (2019). TRA 2 bölgesi akademisyenlerinin bakış açısıyla adli muhasebe eğitimi. Muhasebe ve Finansman Dergisi, (81), 163-182.

Pamukçu, A. (2017). Adli muhasebe ve bağımsız denetim sürecine etkisi. Marmara Üniversitesi Öneri Dergisi, $12(48), 227-244$.

Pazarçeviren, S.Y. (2005). Adli muhasebecilik mesleği. ZKÜ Sosyal Bilimler Dergisi, 1(2), 1-19.

Reinstein, A. \& Lander, G. H. (2004). Estimating economicloss in personal injury cases. The CPA Journal, January. Erişim tarihi: 16.01.2019, http://archives.cpajournal.com/2004/104/text/p52.htm

Türk Dil Kurumu. Erişim tarihi: 14.01.2019, http://www.tdk.gov.tr/index.php?option=com_gts\&view=gts.

Türk Ticaret Kanunu. Erişim tarihi: 14.01.2019, https://www.mevzuat.gov.tr/MevzuatMetin/1.5.6102.pdf. 